\title{
Strategies for Nitrite Replacement in Fermented Sausages and Effect of High Pressure Processing against Salmonella spp. and Listeria innocua
}

\author{
Constanza Maria Lopez ${ }^{1}$, Giuliano Dallolio ${ }^{1}$, Paolo Bonilauri ${ }^{2}$ (D) and Annalisa Rebecchi ${ }^{1, *(D)}$ \\ 1 Department for Sustainable Food Process, Università Cattolica del Sacro Cuore, Via Bissolati 72/74, \\ 26100 Cremona, Italy; constanzamaria.lopez@unicatt.it (C.M.L.); giuliano.dallolio@gmail.com (G.D.) \\ 2 Istituto Zooprofilattico Sperimentale della Lombardia ed Emilia-Romagna (IZSLER), Via Bianchi 9, \\ 25124 Brescia, Italy; paolo.bonilauri@izsler.it \\ * Correspondence: annalisa.rebecchi@unicatt.it
}

Citation: Lopez, C.M.; Dallolio, G.; Bonilauri, P.; Rebecchi, A. Strategies for Nitrite Replacement in Fermented Sausages and Effect of High Pressure Processing against Salmonella spp. and Listeria innocua. Foods 2021, 10 2617. https://doi.org/10.3390/ foods10112617

Academic Editor: Maurizio Cian

Received: 24 September 2021

Accepted: 26 October 2021

Published: 28 October 2021

Publisher's Note: MDPI stays neutral with regard to jurisdictional claims in published maps and institutional affiliations.

Copyright: (c) 2021 by the authors. Licensee MDPI, Basel, Switzerland. This article is an open access article distributed under the terms and conditions of the Creative Commons Attribution (CC BY) license (https:// creativecommons.org/licenses/by/ $4.0 /)$

\begin{abstract}
The development of nitrite-free meat products is a current industrial concern. Many efforts have been attempted to replace the nitrite effect in cured meats colour formation and pathogens control. Our previous work evidenced that lactic acid and a cold ripening were the best hurdle technologies for nitrite-free fermented sausages from metabolomics. In the first part of this work, we investigated the effect of lactic acid compared with both two alternative additives (glucono-D-lactone and a mix of sodium di-acetate/sodium lactate) and with low-nitrite sausages, all of them following either cold or traditional ripening. For this purpose, microbiological analysis, $\mathrm{pH}$, water activity $\left(a_{w}\right)$, and a sensory study were performed. All nitrite-free sausages (cold or traditional ripened) showed quality and safety traits similar to low-nitrite traditionally ripened ones used as control. In addition, sensory study revealed that sausages with lactic acid were the most preferred cold ripened samples, supporting that this is an optimal strategy for the production of nitrite-free sausages. We selected this product for further studies. Indeed, in the second part, we evaluated the impact of ripening, and other hurdle technologies as High Pressure Processing (HPP) and under-vacuum storage against Listeria innocua and Salmonella spp. by a challenge test. Maximal declines were obtained for ripening along with HPP (i.e., 4.74 and $3.83 \log$ CFU/g for L. innocua and Salmonella spp., respectively), suggesting that HPP might guarantee nitrite-free sausages safety. Although the quality of raw materials remains essential, these hurdle strategies largely contributed to nitrite-free sausages safety, offering a promising tool for the meat industry.
\end{abstract}

Keywords: nitrite-free fermented sausages; High Pressure Processing (HPP); Listeria innocua; Salmonella spp.

\section{Introduction}

Nitrites and nitrates have long been used to avoid spoilage and to extend shelf life of meat products. As curing agents, they contribute to meat products colour and flavour. Nitrites have played a key role in inhibiting Clostridium botulinum spores and in preventing food poisoning caused by their toxin [1,2]. Recent findings suggest that nitrites could have an antagonistic effect against Listeria and Salmonella, two major pathogens in meat products, often used as microbiological safety standards [3]. In particular, nitrites and nitrates led to the inhibition of L. innocua in dry cured ham [4], as well as L. monocytogenes and S. enterica serovar Thyphimurium in dry fermented sausages [5,6]. Apart from their multiple benefits, nitrites might produce carcinogenic and mutagenic compounds, such as N-nitrosamines, after a series of chemical reactions in the meat matrix [7]. The concentration of these undesirable compounds greatly depends on the quantity of nitrites and nitrates added to the meat batter, but it is also affected by raw materials quality, processing, and other factors [8]. In this sense, the European Union allows maximal concentrations of $250 \mathrm{ppm}$ of $\mathrm{NaNO}_{3}$, or $150 / 150$ ppm of $\mathrm{NaNO}_{3} / \mathrm{NaNO}_{2}$ for traditional products, as established 
in EC 1129/2011 [9]. On the other hand, meat products labelled as organic foods can have a maximal concentration of $80 \mathrm{ppm}$ of nitrites in the European Union according to EC 780/2006 [10], while in the U.S., the addition of nitrites and nitrates in organic products is forbidden [11].

In the last few years, driven by consumer demands for healthier foods, there has been an increased interest in the development of low-nitrite or nitrite-free meat products, but consumer safety and preserving meat products typical organoleptic characteristics have to be guaranteed. Therefore, a strict selection of raw materials becomes essential to accomplish high-quality standards in nitrite-free products. Since the production chain usually implies a natural contamination, the combination of synergistic hurdle technologies that inactivate or decrease foodborne pathogens without affecting nutritional or sensory traits is required $[12,13]$. In practice, this means improving the manufacturing process by adjusting diverse variables, for example: (i) temperature and time of fermentation and ripening, (ii) final water activity $\left(\mathrm{a}_{\mathrm{w}}\right)$ and $\mathrm{pH}$ values, (iii) use of selected starter culture, and (iv) addition of safe antimicrobial agents such as ascorbic or lactic acids, sodium lactate, sodium acetate, etc.

In addition, to validate the ready-to-eat (RTE) meat-derived food process for export to the U.S. that requires a reduction of 5-log CFU/g [14], additional treatments could be necessary. In this regard, High Pressure Processing (HPP) is currently becoming an industrial reality as an additional hurdle for fermented sausages preservation [15-17]. In fact, HPP represents the only non-thermal process with commercial impact, even when major advances in these technologies have been made around the world [18]. In general, HPP applies a pressure range from 100 to $1000 \mathrm{MPa}$ transmitted by a liquid to a packaged product that inactivates bacteria but only partially inactivates spores. Several mechanisms are implied, such as protein denaturation, although they are not completely understood so far [19-21]. Many authors proposed that this process is able to reduce pathogen bacteria while both technological microbiota and typical sensory characteristics of fermented sausages remain unaltered [22,23].

Actually, there is some evidence that HPP can significantly inhibit Listeria sp. and Salmonella spp. [16,24-27]. Thus, the replacement of nitrites antagonistic effect by this technology may be feasible. Meanwhile, Balamurugan et al. [28] warned about some intrinsic aspects of fermented sausages that may decline the efficiency of HPP-for instance, the complexity of the food product, the high concentrations of $\mathrm{NaCl}$, and the low $\mathrm{a}_{\mathrm{w}}$ values. In addition, resistance to HPP seems to be a strain-dependent characteristic [15,29]. Considering all these facts, the performance of HPP treatment should be individually evaluated for each product by a challenge test to provide insights about the control of undesirable bacteria.

Recently, our group evaluated a novel cold ripening process and the addition of both ascorbic and lactic acids as hurdle technologies in nitrate-free salami [30]. We used a metabolomic approach to find those conditions that avoided case hardening and extreme oxidation of samples. In addition, we hypothesised that this improved process represented an interesting alternative to nitrate/nitrite addition, even though further studies were recommended, such as safety assessment or additional hurdle technologies for final products.

The aim of this study was to evaluate lactic acid addition for nitrite-free sausage production in comparison to two uncommon additives (glucono-D-lactone and a mix of sodium di-acetate/sodium lactate), and low-nitrite sausages, all of them following either cold or traditional ripening. The best strategy for nitrite replacement in fermented sausages was selected for further studies. We investigated the contribution of ripening and other hurdle technologies as under-vacuum storage, and HPP in Listeria innocua and Salmonella spp. inactivation by a challenge test. 


\section{Materials and Methods}

\subsection{Manufacturing of Fermented Sausages with Different Additives}

Fermented sausages were produced in triplicate in a small-scale manufacturer in Northern Italy (Salumificio Santini, Cremona, Italy). The meat came from "Gran Suino Padano PDO", a typical Italian heavy pig with an age of over 9 months and a live weight of over $150 \mathrm{~kg}$, well suited to the production of Italian fermented meat sausages. A mixture of $100 \mathrm{~kg}$ was prepared according to Rocchetti et al. [30]: pork meat (pork leg, defatted boneless pork shoulder, pork neck, $73 \%$ ) and fatty tissues (pork skinned belly, pork throat fat, $23.7 \%)$ trimmed $6 \mathrm{~mm}$, salt $(2.5 \%)$, white wine $(0.3 \%)$, ascorbic acid $(0.2 \%)$, dextrose $(0.15 \%)$, black pepper $(0.08 \%)$, and garlic $(0.01 \%)$. Starter cultures (Teracell, Cremona, Italy) were added in a final concentration of $1 \times 10^{7} \mathrm{CFU} / \mathrm{g}$ for Lactobacillus sakei and $3 \times 10^{6} \mathrm{CFU} / \mathrm{g}$ for two species of staphylococci coagulase negative (CNS), Staphylococcus xylosus and Staphylococcus carnosus. The total meat batter was then divided into five batches (20 kg each), each one with different additives: (1) lactic acid 0.3\% (Chimab, Padova, Italy), (2) glucono-D-lactone $0.6 \%$ (Chimab, Padova, Italy), (3) a mix of sodium di-acetate (E 262) and sodium lactate (E 325) 1.5\% (Opti.Form powder 98, Corbion, The Netherlands), (4) vegetable extracts containing nitrites 80 ppm (Accel ${ }^{\mathrm{TM}}$, Kerry, Ireland), and (5) sodium nitrite 80 ppm (Chimab, Padova, Italy). These last two batches were prepared according to the maximal concentration allowed for organic fermented sausages in Europe and used as low-nitrite controls.

Then, the mixtures were stuffed into $38 \mathrm{~mm}$ diameter collagen casings using a vacuum filler (Handtmann, Biberach, Germany), resulting in sausages of $20-22 \mathrm{~cm}$ length that weighed $370 \mathrm{~g}$, approximately. All the batches (from 1 to 5) were divided into two groups that followed two different ripening processes in drying cabinets (Everlasting, Mantova, Italy) for 35 days, for a total of 10 baches. The "traditional ripening" group (T) followed a first phase set at decreasing temperatures from $22-14{ }^{\circ} \mathrm{C}$ and $65-90 \%$ relative humidity (RH) for $3-5$ days and a second step at $14-12{ }^{\circ} \mathrm{C}$ and $75-85 \%$ RH for $30-32$ days. The "cold ripening" (C) group followed a first step with a temperature range of $6-8{ }^{\circ} \mathrm{C}$ and $65-90 \%$ RH for 20-25 days, until the $\mathrm{a}_{\mathrm{w}}$ value reached $\leq 0.92$, while the second phase had a temperature range of $10-12{ }^{\circ} \mathrm{C}$ and $75-85 \% \mathrm{RH}$ for $10-12$ days. This last process was designed in our previous study [30] to avoid the growth of Clostridium botulinum belonging to Group I or II, as previous studies had found [31]. On the other hand, the traditional ripening provided the standard parameters to evaluate the suitability of the studied cold ripening. Samples were collected before stuffing at time $0\left(t_{0}\right)$ and after 6 days $\left(t_{6}\right), 15$ days $\left(t_{15}\right)$, and 35 days $\left(t_{35}\right)$. Samples of each formulation/condition from the three replicates at a defined time point were taken, weighed, and analysed. For each sample, three sub-samples (from central and at both ends) were pooled and homogenised, then an aliquot was used for further analyses.

\subsection{Microbiological Analysis, $p H$, and Water Activity}

For microbial enumeration, $10 \mathrm{~g}$ of fermented sausage samples were aseptically removed and diluted 1:10 with saline water $(0.9 \% \mathrm{NaCl})$ and homogenised for $1.5 \mathrm{~min}$ at $260 \mathrm{rpm}$ in a Stomacher Lab-Blender (400 Circulator; International PBI, Milan, Italy). Briefly, appropriate decimal dilutions were plated in duplicate onto the following media (Oxoid, Milan, Italy) and incubated under these conditions: Violet Red Bile Glucose Agar (VRBGA) for $24 \mathrm{~h}$ at $37^{\circ} \mathrm{C}$ for Enterobacteriaceae (ISO 21528-2, 2017) [32], Violet Red Bile Agar (VRBA) for $24 \mathrm{~h}$ at $37^{\circ} \mathrm{C}$ for total coliforms, VRBA supplemented with MUG $100 \mu \mathrm{g} / \mathrm{mL}$ for $24 \mathrm{~h}$ at $44^{\circ} \mathrm{C}$ for Escherichia coli, MRS Agar for $72 \mathrm{~h}$ at $30^{\circ} \mathrm{C}$ under restricted oxygen conditions achieved using Anaerocult A (Merck, Darmstadt, Germany) for lactobacilli (ISO 15214, 1998) [33] and Baird Parker Agar added with egg yolk tellurite emulsion at $37^{\circ} \mathrm{C}$ for $48 \mathrm{~h}$ in aerobic conditions for staphylococci (ISO 6888-1, 1999) [34]. Procedures to detect anaerobic sulfite-reducing bacteria (ISO 15213, 2003) [33] and Bacillus cereus (ISO 7932, 2005) [35] were applied. For a challenge test, enumeration of Listeria innocua and Salmonella spp. viable cells were performed by serial dilution and direct surface plating in duplicate onto Agar 
Listeria Ottaviani \& Agosti (Biolife, Milan, Italy), according to ISO 11290-2 [36], and onto XLD agar (Oxoid, Italy). After counts, log CFU/g were calculated for replicates.

To evaluate the natural contamination of meat, analyses were performed in $25 \mathrm{~g}$ of sample for Listeria monocytogenes (ISO 11290-1, 2017) [37] and Salmonella spp. (ISO 6579-1, 2017) [38].

The $\mathrm{pH}$ values were obtained by directly inserting the tip of the electrode $\mathrm{pH} 127-\mathrm{m}$ (692 $\mathrm{pH}$ /Ion Meter-Metrohm, Laramie, Wyoming, USA) into different portions of the samples. For challenge test, the $\mathrm{pH}$ was measured on $10 \mathrm{~g}$ of each sample using an $\mathrm{HI}$ 223 Calibration Check ${ }^{\mathrm{TM}}$ Microprocessor $\mathrm{pH}$ meter (Hanna Instrument, Smithfield, RI, USA) equipped with a Gel-Glass electrode (Hamilton, Bonaduz, Switzerland).

Water activity was measured at $25^{\circ} \mathrm{C}$ by means of the $\mathrm{a}_{\mathrm{w}}$-meter AQUALAB Series 3 Model TE (Decagon Devices, Inc., Pullman, WA, USA), according to ISO procedures (ISO 18787, 2017) [39].

Means and SDs were calculated, as were both an ANOVA test $(p<0.05)$ and Tukey's test, with the use of InfoStat Statistical Software (Universidad de Cordoba, Cordoba, Argentina).

Normality of $\mathrm{pH}$ and $\mathrm{a}_{\mathrm{w}}$ and $\log$ transformed microbiological data were assumed, due to the continuum scale of each variable and normality distribution of mean values used for comparisons (central limit theorem). In any case, in each one way ANOVA comparison, the Bartlett's test for equal variances was tested $(p<0.05)$ and when homocedasticity was not observed a not parametric Kruskal-Wallis test $(p<0.05)$ was used by means of Intercooled STATA 7.0 (Statacorp).

\subsection{Sensory Study}

A panel of eight trained judges evaluated fermented sausages after 35 days of ripening by a preference analysis. Thus, the ten batches $(1,2,3,4$, and 5 from both $C$ and $\mathrm{T}$ groups) were analysed considering the liking of taste (sweetness, sourness, saltiness and spiciness), appearance, aroma, and overall acceptance. These attributes were rated from 1 (lowest qualification) to 9 (maximal qualification) in a hedonic scale. The sensory panel received slices of approximately $5 \mathrm{~g}$ of fermented sausages, without casings, in a sensory room with appropriate light. Samples were served at room temperature on white plastic dishes, coded with a three-digit number. Data were collected, means and SDs were calculated, as were both an ANOVA test $(p<0.05)$ and Tukey's test using InfoStat Statistical Software (Universidad de Cordoba, Argentina). From the raw data, a Principal Component Analysis (PCA) was performed also using InfoStat Statistical Software. Normality of sensory dataset was tested by Shapiro-Wilk test, null hypothesis states that the variable is normally distributed with $p<0.05$.

\subsection{Challenge Test}

\subsubsection{Preparation of Inoculums}

The complete list of the strains used for the inoculations of Listeria innocua and Salmonella spp. is reported in Table 1. A mixture of three strains of Salmonella: S. enterica serovar Derby strain 106463/1 and monophasic S. enterica serovar Typhimurium antigenic formula 1,4, [5], 12:i: 118174/1 belonging to the IZSLER collection (Istituto Zooprofilattico Sperimentale della Lombardia ed Emilia Romagna, Italy) isolated from pork meat and fresh pork sausage, respectively and S. enterica serovar Typhimurium ATCC14018, were used. For L. innocua inoculation, five strains IZSLER 111373/1, IZSLER 111373/2, IZSLER 257529/1 and IZSLER 257529/2 (isolated from pork meat), and ATCC 33090 were employed as the surrogates of L. monocytogenes. 
Table 1. Strains used for inoculation of L. innocua and Salmonella spp.

\begin{tabular}{|c|c|c|}
\hline Identification Number & Specie & Source of Isolation \\
\hline IZSLER 111373/1 & L. inпосиа & $\begin{array}{c}\text { Environmental swab of } \\
\text { sausage factory }\end{array}$ \\
\hline IZSLER 111373/2 & L. innocua & $\begin{array}{c}\text { Environmental swab of } \\
\text { sausage factory }\end{array}$ \\
\hline IZSLER 257529/1 & L. innocua & Fresh sausage \\
\hline IZSLER $257529 / 2$ & L. innocua & Pork meat \\
\hline ATCC 33090 & L. innocua & Cow brain \\
\hline IZSLER 118174/1 & $\begin{array}{l}\text { S. enterica subsp. enterica } \\
\text { serovar Typhimurium }\end{array}$ & Fresh sausage \\
\hline IZSLER 106463/1 & S. enterica serovar Derby & Pork meat \\
\hline ATCC 14028 & $\begin{array}{l}\text { S. enterica subsp. enterica } \\
\text { serovar Typhimurium }\end{array}$ & Animal tissues \\
\hline
\end{tabular}

Strains were individually inoculated in Brain Heart Infusion broth (BHI, Oxoid) and incubated at $30^{\circ} \mathrm{C}$ for $24 \mathrm{~h}$ in aerobic conditions. The bacterial cultures were prepared as reported by Bonilauri et al. [24] to obtain for each strain a concentration of about $10^{9} \mathrm{CFU} / \mathrm{mL}$. Then, each strain was mixed together in order to achieve a final concentration of approximately $10^{7} \mathrm{CFU} / \mathrm{g}$ of each cocktail in the sausage mixture.

\subsubsection{Production of Nitrite-Free Fermented Sausages and HPP Treatment}

A meat batter of $60 \mathrm{~kg}(n=3)$ was prepared according to the basic recipe described below, with the addition of lactic acid 3\%. The batter was thoroughly mixed and then divided into two batches: one inoculated with the mix of L. innocua $(\mathrm{L})$ and the other inoculated with the mix of S. enterica (S). Before inoculation, five samples (around $25 \mathrm{~g}$ ) of each batch were investigated for the presence/absence of Listeria sp. (ISO 11290-1, 2017) [37] and Salmonella spp. (ISO 6579-1, 2017) [38] to evaluate the natural contamination of meat.

The cold ripening process was applied to all sausage samples: $6-8{ }^{\circ} \mathrm{C}$ and $65-90 \% \mathrm{RH}$ for $20-25$ days, and $10-12{ }^{\circ} \mathrm{C}$ and $75-85 \%$ RH for $10-12$ days. After 35 days, samples were peeled and vacuum packed (GK600/610 B Series, SUPERVAC, Mödling, Austria), and half of the samples of each batch $S$ and $L$ were stored at $12-14{ }^{\circ} \mathrm{C}$ for other 30 days $\left(\mathrm{t}_{65}\right)$, whilst the other half were submitted to HPP treatment (Iperbaric, Burgos, Spain) using $593 \mathrm{MPa}$ for $290 \mathrm{~s}$ and water at $14{ }^{\circ} \mathrm{C}$.

Samples were analysed in triplicate at time 0 (before stuffing), 6 days (at the end of acidification step), 35 days (before and after HPP treatment), and 65 days for the non-treated samples with HPP for microbiological and physicochemical studies. Then, we determined the bacteria variations due to ripening, HPP, or storage by calculating the difference $(\Delta)$ of the average counts for two different samplings $\left(\mathrm{N}_{1}, \mathrm{~N}_{2}\right)$ expressed in $\log \mathrm{CFU} / \mathrm{g}$, as follows: $\Delta=\log \left(\mathrm{N}_{2} / \mathrm{N}_{1}\right)$.

\section{Results and Discussion}

The complete workflow of this study is represented in Figure 1. 


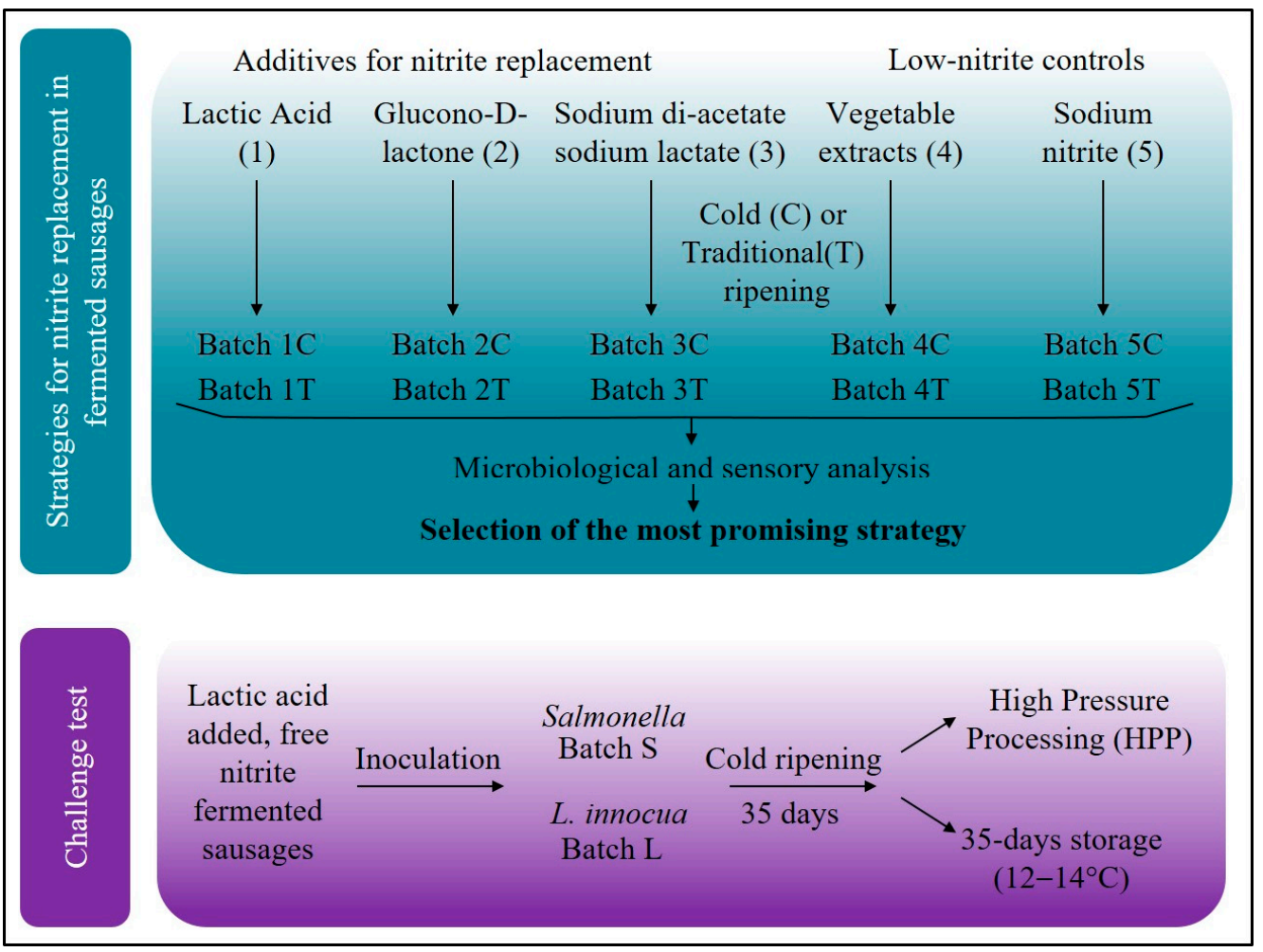

Figure 1. Workflow of the experimental design showing the two steps of this study: at first a comparison among additives and ripening conditions to select the most promising nitrite-free fermented sausages and at the second step it was submitted to challenge test. Additives used for different batches are indicated as 1: lactic acid; 2: glucono-D-lactone; 3: sodium acetate/sodium lactate; 4: nitrites from vegetables $(80 \mathrm{ppm})$; 5 : sodium nitrite $(80 \mathrm{ppm})$. Groups following different ripening conditions are indicated as T: traditional ripening; $C$ : cold ripening. Batch S: inoculated with Salmonella spp. Batch L: inoculated with L. innocua.

\subsection{Effect of Additives and Ripening Conditions on Fermented Sausages Quality}

\subsubsection{Microbiological and Physicochemical Analysis}

Enumeration of main bacterial groups of fermented sausages was performed for samples containing different additives in alternative to nitrite: lactic acid, glucono-D-lactone, and a mix of sodium di-acetate and sodium lactate. In addition, two different low-nitrite fermented sausages were used as controls, both containing $80 \mathrm{ppm}$ of nitrite, either as natural extracts or as inorganic nitrite $\left(\mathrm{NaNO}_{2}\right)$. Each one of these five different batches followed a cold ( $\mathrm{C}$ group) or a traditional ( $\mathrm{T}$ group) ripening. Results for the ten batches along the 35-day ripening conditions are shown in Table S1. Counts of lactobacilli for the ten batches started with values in the range of $6.51 \pm 0.01 \log$ CFU/g to $6.62 \pm 0.06 \log$ CFU/g, without significant differences among samples. With regard to the $C$ group, no significant differences were observed among samples with or without nitrites after 30 days, reaching counts between $8.07 \pm 0.16 \log \mathrm{CFU} / \mathrm{g}$ and $8.83 \pm 0.62 \mathrm{log} \mathrm{CFU} / \mathrm{g}$. In addition, these values were similar to those found for the T group at 30 days. However, growth trends exhibited certain differences between samples with the same additive but with diverse ripening. In fact, the highest number of lactobacilli was achieved at day 30 for the $\mathrm{C}$ group, while it was registered earlier $\left(a t t_{15}\right)$ for the T group, as expected. CNS counts at the initial time were in a range of $6.31 \pm 0.14 \log \mathrm{CFU} / \mathrm{g}$ and $6.52 \pm 0.07 \mathrm{log} \mathrm{CFU} / \mathrm{g}$ for the ten batches, without significant differences among them. In general, counts increased until day 4 , and then remained almost unchanged for all batches. However, as an exception, the low-nitrite samples from the $C$ group (batches $4 C$ and $5 C$ ) presented the maximum values after 15 days. CNS counts presented values comprised between $7.15 \pm 0.68 \log$ CFU/g and $7.89 \pm 0.03 \log \mathrm{CFU} / \mathrm{g}$ at the end of the ripening for all the batches. No significant 
differences among them were observed, neither for nitrite-free sausages with the same additives but different ripening conditions. Interestingly, even though temperature is a main factor in the regulation of bacteria growth, the starter cultures seemed to be appropriately adapted to the cold ripening, as registered in our previous work [30]. In addition, our results showed the lack of nitrite influence on lactobacilli development; still, some effect could be noticed for staphylococci in samples following the cold ripening, since a slower growth was observed for batches with nitrites compared to nitrite-free sausages. Controversial results about the influence of nitrite/nitrate in staphylococci development have been found, as already discussed in Christieans et al. [5]. In this sense, Hospital et al. [6] reported staphylococci inhibition at the end of ripening using higher concentrations of nitrite and nitrate (150 ppm each) than those used herein.

For Enterobacteriaceae, counts were lower than or equal to $100 \mathrm{CFU} / \mathrm{g}$ for all the batches at the initial time, demonstrating a remarkably high quality of raw materials, and particularly, of the pork meat used. Counts $<10 \mathrm{CFU} / \mathrm{g}$ were obtained at 15 and 30 days for the $\mathrm{T}$ and $\mathrm{C}$ groups, respectively. Enterobacteriaceae inhibition coincided with the maximal growth of lactobacilli that usually exerts some antimicrobial activity due to the acidification of the meat matrix and microbial competition. It could be underlined that no differences were found among nitrite-free and low-nitrite samples at the same ripening condition. Therefore, low temperatures, not nitrites, mainly affected Enterobacteriaceae viability in this study, where high quality raw materials were used.

A similar drop was obtained only when high amounts of nitrate/nitrite (150 ppm/125 ppm) were used in Fabriano-like fermented sausages at the same time of ripening [40]. These results allowed us to suggest that temperatures and raw materials quality seemed to be the key variables that contributed to safety enhancement of nitrite-free sausages. Besides, E. coli, as well as vegetative cells and spores of both sulfite-reducing bacteria and B. cereus, were always lower than $10 \mathrm{CFU} / \mathrm{g}$, whereas L. monocytogenes and Salmonella spp. were not detected in all samples during the whole process. Therefore, no food safety issues could be attributed to these fermented sausages, even in the absence of nitrites.

Regarding physicochemical parameters (Table S2), samples showed values in the range of 5.14 $\pm 0.03-5.69 \pm 0.01$ for $\mathrm{pH}$ and $0.975 \pm 0.001-0.980 \pm 0.002$ for $\mathrm{a}_{\mathrm{w}}$ at the initial time. It is worth noting that the addition of lactic acid and glucono-D-lactone (batches 1 and 2) led to $\mathrm{pH}$ values $\leq 5.2$ at the beginning of fermentation, and then no further $\mathrm{pH}$ reductions were observed along ripening in both conditions. This acidification was conducted to inhibit pathogen bacteria from forming. In fact, Mataragas et al. [41] highlighted the importance of rapidly decreasing the $\mathrm{pH}$ in the first $48 \mathrm{~h}$ of fermentation for a quicker inactivation of L. monocytogenes, as had occurred in salame Cacciatore. In this work, the $\mathrm{pH}$ values of batches 3, 4, and 5 (those not having acidifying additives) were closely related to temperature and lactobacilli counts, instead. The physicochemical parameters of cold ripened samples exhibited slightly higher $\mathrm{pH}$ and $\mathrm{a}_{\mathrm{w}}$ values than those traditional ripened samples at $t_{15}$ and $t_{30}$, reaching final values between $5.33 \pm 0.04$ and $5.48 \pm 0.01$ for $\mathrm{pH}$ and between $0.894 \pm 0.003$ and $0.898 \pm 0.001$ for $\mathrm{a}_{\mathrm{w}}$. Results obtained for the cold ripening can be considered satisfactory for fermented sausages and appropriate to prevent undesired bacteria growth when high quality raw materials are used.

\subsubsection{Sensory Study}

A trained panel performed a preference study of samples from the ten batches at the end of the ripening. The analysed attributes included sweetness, sourness, saltiness, spiciness, appearance, aroma, and overall acceptance (Figure S1). These attributes were considered to find the most preferred cold ripened nitrite-free sausages in terms of organoleptic characteristics. The whole data were analysed by using Principal Components Analysis (PCA) and graphically represented by a biplot (Figure 2) that accounted for a total of $95 \%$ of the explained variability. This PCA showed that the panel most preferred the two samples containing inorganic nitrites (batches 5C and 5T), followed by the samples with natural nitrites (batches $4 \mathrm{C}$ and $4 \mathrm{~T}$ ). For nitrite-free sausages, samples containing lactic acid from 
the $C$ group (batch 1C) followed by the glucono-D-lactone-added sample from the T group (batch 2T) were the best scored. On the contrary, the samples containing sodium di-acetate and sodium lactate from both groups ( $3 \mathrm{C}$ and $3 \mathrm{~T}$ ) were the worst rated, suggesting that these compounds might affect sensory traits.

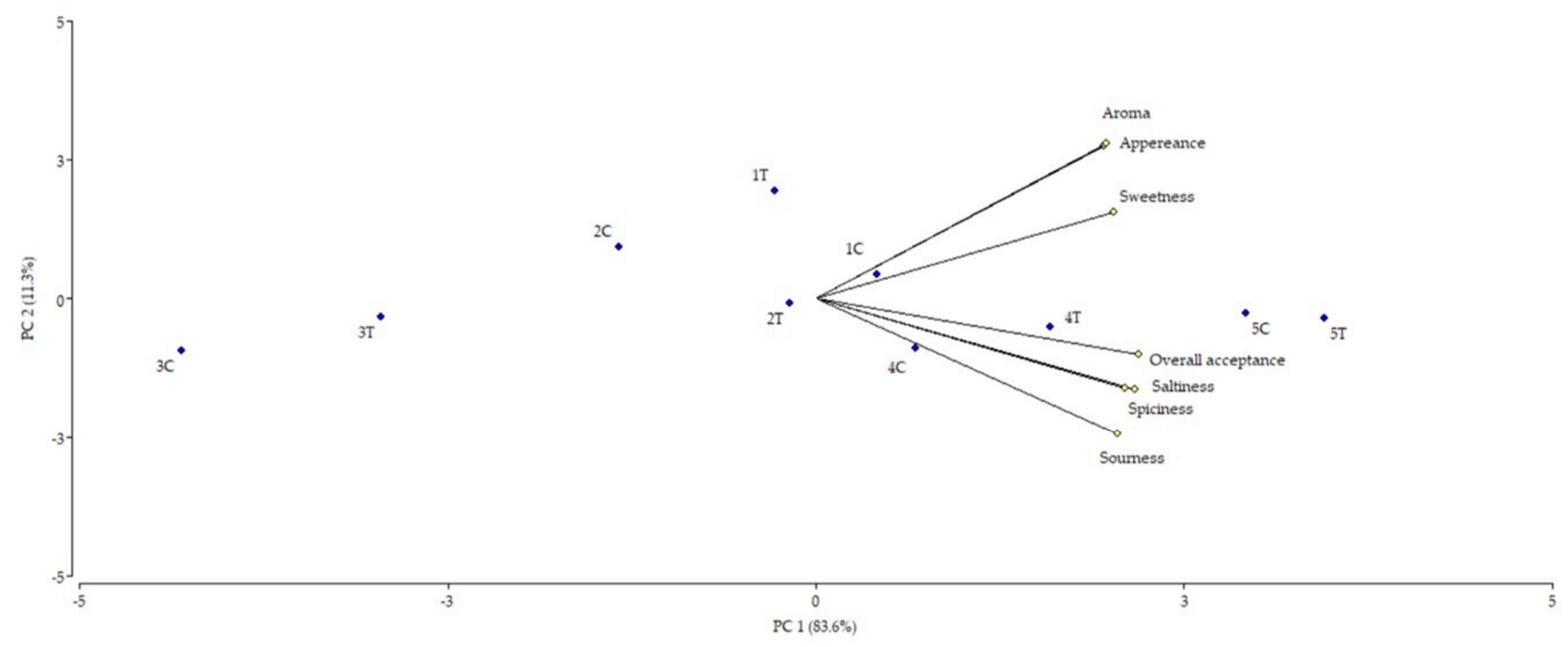

Figure 2. Principal component Analysis (PCA) of the sensory study conducted to the ten batches considering appearance, aroma, sweetness, spiciness, saltiness, sourness, and overall acceptance.

From the evaluated attributes, appearance that includes diverse characteristics, such as colour, cohesiveness, and oily appearance, has an especial interest. Nitrite is a key component for colour development of fermented sausages due to the nitrosomyoglobin pigment, which gives sausages their typically cured appearance. Nitrite elimination often leads to colour depletion, and its replacement, often with natural antimicrobials, rarely contributes to colour formation $[8,42,43]$. Many efforts have been conducted to evaluate natural substitutes for nitrite in diverse meat products that could provide other additional benefits, but colour remains an issue [44-46]. Considering appearance in our study, the best scored nitrite-free sausages were those with lactic acid: $8.00 \pm 0.00$ for batch $1 \mathrm{C}$ and $7.80 \pm 0.45$ for batch $1 \mathrm{~T}$. These values were similar to samples with inorganic nitrite $(8.20 \pm 0.45$ for $5 \mathrm{C}$ and $8.00 \pm 0.71$ for $5 \mathrm{~T})$ and even better than those with added natural nitrites $(6.80 \pm 0.84$ for batch $4 \mathrm{C}$ and $7.40 \pm 0.55$ for batch $4 \mathrm{~T})$. In addition, values for samples with lactic acid were better scored than glucono-D-lactone $(7.20 \pm 0.44$ for batch $2 \mathrm{C}$ and $6.60 \pm 0.45$ for batch $2 \mathrm{~T})$ and sodium di-acetate and sodium lactate $(4.80 \pm 0.44$ for batch $3 C$ and $5.40 \pm 0.54$ for batch $3 \mathrm{~T}$ ). It is worth noting that lactic acid likely improved the sausages appearance, without drawbacks in taste, as not clear differences in sourness were found among samples. From these results, lactic acid represents a suitable alternative to nitrite-free fermented sausages. Furthermore, the combination of these two hurdle technologies (i.e., lactic acid and cold ripening) might be a promising strategy for the production of nitrite-free sausages based on microbiological, physicochemical, and sensory traits, including low hardening and oxidation, as previously determined by metabolomics and T-BARS studies [30].

\subsection{Effect of Ripening, HPP, and Storage on L. innocua and Salmonella spp. Growth in Nitrite-Free Fermented Sausages}

Challenge tests against L. innocua sp. and Salmonella spp. were applied to nitritefree fermented sausages following our previous work [30]. Before inoculation, the meat batter was investigated for Listeria sp. and Salmonella spp., and their absences in $25 \mathrm{~g}$ of sample were verified. For each challenge test, a cocktail of strains was prepared and then inoculated (around $7 \log$ CFU/g), obtaining two batches, L and S, for L. innocua and 
Salmonella spp., respectively. Samples were subjected to 35 days of cold ripening, and then the HPP treatment (593 MPa for $290 \mathrm{~s}$ ) to the half of them was applied. The non-treated samples were stored at $12-14{ }^{\circ} \mathrm{C}$ in vacuum packaging for an additional 30 days. Counts of Listeria sp. or Salmonella spp., lactobacilli, and staphylococci, as well as $\mathrm{pH}$ and $\mathrm{a}_{\mathrm{w}}$ values, were assessed after 0, 6 days, 35 days (before and after HPP treatment), and 65 days (for the non-treated samples) (Table 2).

Table 2. Counts (log CFU/g) of L. innocua, Salmonella spp., lactobacilli, and staphylococci coagulase negative (CNS) and physico-chemical parameters during challenge test. Bacteria variations $(\Delta)\left[\log \left(\mathrm{N}_{2} / \mathrm{N}_{1}\right)\right]$ were calculated by step.

\begin{tabular}{|c|c|c|c|c|c|c|}
\hline Time (Days) & L. innocua & Salmonella & Lactobacilli & CNS & $\mathrm{pH}$ & $\mathbf{a}_{\mathbf{w}}$ \\
\hline 0 & $7.12 \pm 0.01^{\mathrm{e}}$ & $6.87 \pm 0.05^{\mathrm{d}}$ & $6.96 \pm 0.09^{a}$ & $6.62 \pm 0.10^{c}$ & $5.22 \pm 0.01^{\mathrm{a}}$ & $0.971 \pm 0.001^{\mathrm{c}}$ \\
\hline 6 & $6.41 \pm 0.03^{d}$ & $7.03 \pm 0.08^{d}$ & $8.12 \pm 0.24^{c}$ & $6.93 \pm 0.18^{c}$ & $5.25 \pm 0.02^{\mathrm{a}}$ & $0.964 \pm 0.003^{c}$ \\
\hline 35 (before HPP) & $5.54 \pm 0.12^{\mathrm{c}}$ & $6.02 \pm 0.13^{c}$ & $8.00 \pm 0.29^{c}$ & $7.27 \pm 0.35^{c}$ & $5.25 \pm 0.03^{\mathrm{a}}$ & $0.896 \pm 0.007^{b}$ \\
\hline 35 (after HPP) & $2.38 \pm 0.42^{\mathrm{a}}$ & $3.04 \pm 0.07^{\mathrm{a}}$ & $6.73 \pm 0.42^{\mathrm{a}}$ & $3.73 \pm 0.54^{\mathrm{a}}$ & ND & ND \\
\hline 65 (Non-treated) & $4.78 \pm 0.17^{\mathrm{b}}$ & $3.94 \pm 0.26^{b}$ & $7.46 \pm 0.24^{b}$ & $5.40 \pm 0.71^{b}$ & $5.34 \pm 0.03^{b}$ & $0.882 \pm 0.008^{a}$ \\
\hline$\Delta\left[\log \left(\mathrm{N}_{2} / \mathrm{N}_{1}\right)\right]$ & L. innocua & Salmonella & Lactobacilli & CNS & & \\
\hline$\Delta$ Ripening & -1.58 & -0.85 & 1.05 & 0.65 & & \\
\hline$\Delta \mathrm{HPP}$ & -3.16 & -2.98 & -1.27 & -3.54 & & \\
\hline$\Delta$ Ripening $+\Delta \mathrm{HPP}$ & -4.74 & -3.83 & -0.23 & -2.89 & & \\
\hline$\Delta$ Storage & -0.76 & -2.07 & -0.54 & -1.87 & & \\
\hline$\Delta$ Ripening $+\Delta$ Storage & -2.34 & -2.92 & 0.51 & -1.22 & & \\
\hline
\end{tabular}

Letters as superscripts indicate significant differences by column based on ANOVA and Tukey's test ( $p<0.05)$. HPP: High Pressure Processing. ND: not determined. $\triangle$ Ripening $=\log \mathrm{CFU} / \mathrm{g}$ at the time $0-\log \mathrm{CFU} / \mathrm{g}$ at the end of the ripening (35 days before HPP); $\Delta \mathrm{HPP}=\log \mathrm{CFU} / \mathrm{g}$ before HPP $-\log \mathrm{CFU} / \mathrm{g}$ after HPP; $\Delta$ Ripening $+\Delta \mathrm{HPP}$ : sum of $\Delta$ Ripening and $\Delta \mathrm{HPP} ; \Delta \mathrm{Storage}=\log \mathrm{CFU} / \mathrm{g}$ at the time 65 days $-\log$ CFU/g at the time 35 days (before HPP); $\Delta$ Ripening $+\Delta$ Storage: sum (log CFU/g) of $\Delta$ Ripening and $\Delta$ Storage.

Considering media values of both $\mathrm{L}$ and $\mathrm{S}$ batches, lactobacilli reported values of $6.96 \pm 0.09 \log \mathrm{CFU} / \mathrm{g}$ at the initial time and achieved $8.00 \pm 0.29 \mathrm{log} \mathrm{CFU} / \mathrm{g}$ at the end of ripening (Table 2). After the pressurisation, lactobacilli suffered a decline of $1.27 \log \mathrm{CFU} / \mathrm{g}$, while their counts were quite stable (reduction of $0.54 \mathrm{log} \mathrm{CFU} / \mathrm{g}$ ) after storage for non-treated samples. CNS started with values of $6.62 \pm 0.10 \mathrm{log} \mathrm{CFU} / \mathrm{g}$ and increased until $7.27 \pm 0.35 \mathrm{log} \mathrm{CFU} / \mathrm{g}$ at the end of ripening. Then, HPP led to a decrease of $3.54 \log$ CFU/g. Conversely, a reduction of $1.87 \log$ CFU/g at the end of storage for non-treated samples was observed. The significant effect of HPP on lactobacilli and staphylococci allowed us to infer that this treatment could be used only when these technological microorganisms have already accomplished their function, as Marcos et al. [47] had previously observed. Regarding physicochemical parameters, media values for both $\mathrm{L}$ and $\mathrm{S}$ batches started at 5.22 and 0.971 for $\mathrm{pH}$ and $\mathrm{a}_{\mathrm{w}}$, respectively. While minor changes in $\mathrm{pH}$ values were registered (minimum $\mathrm{pH}$ value of $5.12 \pm 0.02$ was achieved at the 20th day, data not shown), the $\mathrm{a}_{\mathrm{w}}$ values decreased until 0.896 at the end of the ripening. These parameters remained almost invariable in the vacuum package during storage at low temperatures. In general, $\mathrm{pH}$ and $\mathrm{a}_{\mathrm{w}}$ values followed similar trends to those found in the previous trials described herein.

For the batch L, L. innocua strains were inoculated in a media concentration of $7.12 \log$ CFU / g and correctly homogenised as SD was $<0.5$ during the whole experiment (Table 2). A reduction of L. innocua counts of 0.71 and $1.58 \log$ CFU/g after fermentation phase $\left(t_{6}\right)$ and at the end of ripening, respectively was observed. When sausages were subjected to HPP (at pH 5.24 and $\mathrm{a}_{\mathrm{w}}$ 0.895), an additional inactivation by $3.16 \log$ CFU/g was obtained, achieving a total reduction of $4.74 \log \mathrm{CFU} / \mathrm{g}$ for the whole process. On the other hand, L. innocua counts also exhibited a significant decrease $(0.76 \log$ CFU/g) during storage (non HPP-treated samples).

The cold ripening process induced a higher inactivation of $\mathrm{L}$. innocua ( $\Delta$ ripening $=1.58 \log \mathrm{CFU} / \mathrm{g}$ ) compared with other author findings for products with similar characteristics. For instance, Bonilauri et al. [25] reported an inactivation less than $1 \log$ CFU/g of L. innocua during ripening for three diverse samples of salame Cacciatore with similar calibre (38 $\mathrm{mm})$, ripening time (34 days), and final $\mathrm{a}_{\mathrm{w}}$ value (0.896). These lower values could be related to the higher 
$\mathrm{pH}$ values during fermentation (5.38) and seasoning (5.52). In addition, $1 \mathrm{log}$ CFU/g was the maximal reduction of L. monocytogenes for French products after 35 days of ripening but only using of $80 / 80$ or $120 / 120 \mathrm{ppm}$ of $\mathrm{NaNO}_{3} / \mathrm{NaNO}_{2}$ [5]. Our results for L. innocua strains are similar to those reported for $L$. monocytogenes in fermented sausages $[5,48]$.

All these facts highlight the main importance of the EC Regulation 2073/2005 [49] that established the no-growth limits for L. monocytogenes: $\mathrm{pH} \leq 4.4$ or $\mathrm{a}_{\mathrm{w}} \leq 0.92$ or $\mathrm{pH} \leq 5.0$ and $\mathrm{a}_{\mathrm{w}} \leq 0.94$. Regarding HPP, our treatment greatly improved the rate of L. innocua inactivation $(\triangle \mathrm{HPP}=3.16 \log \mathrm{CFU} / \mathrm{g})$ in nitrite-free fermented sausages, whereas the complete inactivation ( $\Delta$ ripening $+\mathrm{HPP}=4.74 \log \mathrm{CFU} / \mathrm{g}$ ) allowed us to achieve decay values near the exportation requirements for the U.S. (reduction $\geq 5 \log$ ). On the other hand, Bonilauri et al. [25] observed a clearly minor inhibition of L. innocua (1.60 log CFU/g) after HPP treatment (600 MPa for $300 \mathrm{~s}$ ) in salame Cacciatore. Besides, controversial results could be found in literature about the inhibition of L. monocytogenes in other meat products by HPP. For instance, high levels of inactivation (around $4 \log \mathrm{CFU} / \mathrm{g}$ ) were reported in RTE meats using $600 \mathrm{MPa}, 180 \mathrm{~s}$, and $20^{\circ} \mathrm{C}$ [50], while no inactivation was detected in sliced fermented sausages $\left(600 \mathrm{MPa}, 5 \mathrm{~min}, 12^{\circ} \mathrm{C}\right)$, which was attributed to low $\mathrm{a}_{\mathrm{w}}$ (around 0.880) values and lactate content [26]. In general, these differences could be due to diverse $\mathrm{a}_{\mathrm{w}}$ values, solute composition, and $\mathrm{pH}$ parameters, as well as strain-dependent resistance to HPP. Moreover, even when a notable reduction by HPP was obtained in our study, the inhibition throughout under-vacuum storage ( $\Delta$ storage $=0.76 \log C F U / g)$ was not negligible. Recently, Gonzalez-Fandos et al. [51] reported a similar inactivation of L. monocytogenes in sliced Riojano Chorizo RTE fermented sausage stored for 28 days at $3{ }^{\circ} \mathrm{C}$ under-vacuum.

For the batch S, Salmonella spp., counts of $6.87 \log$ CFU/g were found at the initial time, with an adequate $\mathrm{SD}$ for the entire experiment $(\mathrm{SD}<0.5)$ (Table 2). After 35 days of ripening, a decrease of $0.85 \log \mathrm{CFU} / \mathrm{g}$ was observed. A further $2.98 \log \mathrm{CFU} / \mathrm{g}$ inactivation was obtained by HPP treatment when samples had a pH of 5.25 and $\mathrm{a}_{\mathrm{w}}$ of 0.897 . These two processes led to an overall drop of $3.83 \log$ CFU/g for Salmonella spp. For the non-treated samples, the reduction of Salmonella spp. counts was $2.07 \mathrm{log} \mathrm{CFU} / \mathrm{g}$ after the additional 30 days of storage. In general, the inactivation of Salmonella spp. might be enhanced by using high temperatures of fermentation due to a fast $\mathrm{pH}$ decline, as has often occurred in Northern European fermented meat products [52]. However, Salmonella spp. inhibition in Mediterranean sausages, where mild temperatures are regularly used, has been mostly attributed to $\mathrm{a}_{\mathrm{w}}$ value diminution, but many factors are implied [53]. For instance, S. Typhimurium experienced a comparable decreased inhibition rate in French fermented sausages after 35 days of ripening to the effect of $80 / 80 \mathrm{ppm}$ of $\mathrm{NaNO}_{3} / \mathrm{NaNO}_{2}$ $(0.86 \log \mathrm{CFU} / \mathrm{g})$ or $120 / 120 \mathrm{ppm}$ of $\mathrm{NaNO}_{3} / \mathrm{NaNO}_{2}(1.03 \log \mathrm{CFU} / \mathrm{g})$ [5]. When a large number of Italian sausages containing nitrite/nitrate was studied, Salmonella spp. reduction was in the range of 0.70-3.32 log CFU/g, including a diminution of $1.40 \log \mathrm{CFU} / \mathrm{g}$ in salame Cacciatore [24]. These authors found that inactivation had a high correlation with $\mathrm{pH}$ value at the end of acidification (4.78-5.39), $\mathrm{a}_{\mathrm{w}}$ value at the end of ripening (0.881-0.949), seasoning duration (21-90 days), and salami calibre (60-120 mm).

Differences could be explained by the possible contribution of other factors beyond $\mathrm{a}_{\mathrm{w}}$ value, such as starter cultures, antimicrobial products, or nitrite/nitrate effects, among others. Nevertheless, it could be underlined that a considerable inactivation level was achieved in our study after ripening ( $\Delta$ ripening $=0.85 \log \mathrm{CFU} / \mathrm{g}$ ), which is especially impressive since no nitrates or nitrites were added. Regarding the impact of $\mathrm{HPP}$ on Batch S, this treatment provided a greater contribution to Salmonella spp. reduction $(\triangle \mathrm{HPP}=2.98 \log \mathrm{CFU} / \mathrm{g})$ than ripening or storage. Besides, this inhibitory effect was in the range reported by other authors for traditional Italian fermented sausages (5.84-1.87 $\log \mathrm{CFU} / \mathrm{g})$, although a greater reduction (3.72 $\log \mathrm{CFU} / \mathrm{g}$ ) in a similar sausage (salame Cacciatore) had been previously observed [24]. Interestingly, our study observed a notable decrease ( $\Delta$ storage $=2.07 \log \mathrm{CFU} / \mathrm{g}$ ) of Salmonella spp. during storage that could be associated with the long exposure to low $\mathrm{a}_{\mathrm{w}}$ values, considering that the non-growth- 
permitting $\mathrm{a}_{\mathrm{w}}$ value is $\leq 0.94$ for Salmonella spp. [54]. However, several studies have shown that reduced $\mathrm{a}_{\mathrm{w}}$ values protect against the inactivation of Salmonella spp. in low-moisture foods (e.g., chocolate, nuts, etc.) [55,56].

Our findings are in line with those of Mataragas et al. [41], who observed that the $\mathrm{a}_{\mathrm{w}}$ reduction had becomes more important than the reduction in $\mathrm{pH}$ value to control foodborne pathogens such as Salmonella spp. in fermented sausages slowly acidified with fermentation temperatures $<20^{\circ} \mathrm{C}$. Comparing Salmonella spp. and L. innocua inactivation, our results indicated clear differences in their trends during ripening and storage. L. innocua strains seemed to be more susceptible than Salmonella spp. in our particular ripening conditions (lactic acid addition, low temperatures, as well as slow decreases of $\mathrm{pH}$ and $\mathrm{a}_{\mathrm{w}}$ values). This is in contrast with other author findings that suggested that Gram positive bacteria are more resistant than Gram negative bacteria to the hurdle technologies applied in standard conditions of fermentation and ripening [41]. On the contrary, Salmonella spp. seemed to be more susceptible than L. innocua during storage when the $\mathrm{a}_{\mathrm{w}}$ value was lower, and the $\mathrm{pH}$ was slightly higher than ripening. These variations could be partially explained by differences among specie or strains of Listeria sp. and Salmonella spp., although the influence of the conditions applied in our study may not be discarded.

Considering HPP, there is much evidence that demonstrated the influence of several factors, such as sodium chloride, sugar, fat content, and low $\mathrm{a}_{\mathrm{w}}$ value in treatment efficiency, against diverse microorganisms [57-60]. Our results exhibited divergences in the inactivation levels observed by diverse authors could be attributed to the particular characteristics of each product and its processing. It is worth noting that the concentration of the inoculum of Salmonella spp. and L. innocua used in these challenge tests was designed to explore the maximal inhibitory capability of HPP. The inactivation levels found in our work could be relevant against the actual contamination in the processing chain of fermented sausages. Therefore, we agree with the evaluation of HPP performance by challenge tests addressed to a particular product in the real conditions of consumption or commercialisation.

\section{Conclusions}

Our results confirmed that cold ripening, combined with the addition of lactic acid $3 \%$ in fermented sausages, might replace the effect of nitrite without affecting sausages appearance or microbiological and physicochemical traits. In addition, our study complements our previous findings where the metabolomic approach allowed a deep analysis of fermented sausages quality correlated to both correct microbial development and desired biochemistry reactions. Finally, our findings emphasised the value of HPP as a final hurdle technology in nitrite-free fermented sausages because it exerted a main role in L. innocua and Salmonella spp. control. However, the use of high-quality raw materials is still mandatory to assure safety of these products.

Supplementary Materials: The following are available online at https:/ / www.mdpi.com/article/10 .3390 / foods10112617/s1, Figure S1: Spider chart of sensory attributes for the ten batches. Additives used for different batches 1: lactic acid; 2: glucono-D-lactone; 3: sodium acetate/sodium lactate; 4: nitrites from vegetables $(80 \mathrm{ppm})$; 5: sodium nitrite (80 ppm). T: traditional ripening; C: cold ripening. Table S1: Counts (log CFU/g) of lactobacilli, staphylococci coagulase negative (CNS), and Enterobacteriaceae for the ten batches. Table S2: $\mathrm{pH}$ and aw values for the ten batches

Author Contributions: Conceptualization, G.D., P.B. and A.R.; methodology, A.R.; formal analysis, C.M.L.; investigation, P.B.; data curation, C.M.L., G.D., P.B.; writing-original draft preparation, C.M.L.; writing-review and editing, A.R.; supervision, A.R. All authors have read and agreed to the published version of the manuscript.

Funding: This research received no external funding.

Institutional Review Board Statement: Not applicable.

Informed Consent Statement: Not applicable.

Data Availability Statement: Not applicable. 
Conflicts of Interest: The authors declare no conflict of interest.

\section{References}

1. Cammack, R.; Joannou, C.L.; Cui, X.Y.; Torres Martinez, C.; Maraj, S.R.; Hughes, M.N. Nitrite and nitrosyl compounds in food preservation. Biochim. Biophys. Acta Bioenerg. 1999, 1411, 475-488. [CrossRef]

2. Honikel, K.O. The use and control of nitrate and nitrite for the processing of meat products. Meat Sci. 2008, 78, 68-76. [CrossRef] [PubMed]

3. EFSA; ECDC. The European Union summary report on trends and sources of zoonoses, zoonotic agents and food-borne outbreaks in 2015. EFSA J. 2016, 14, 20449. [CrossRef]

4. Hospital, X.F.; Hierro, E.; Arnau, J.; Carballo, J.; Aguirre, J.S.; Gratacós-Cubarsí, M.; Fernández, M. Effect of nitrate and nitrite on Listeria and selected spoilage bacteria inoculated in dry-cured ham. Food Res. Int. 2017, 101, 82-87. [CrossRef]

5. Christieans, S.; Picgirard, L.; Parafita, E.; Lebert, A.; Gregori, T. Impact of reducing nitrate/nitrite levels on the behavior of Salmonella Typhimurium and Listeria monocytogenes in French dry fermented sausages. Meat Sci. 2018, 137, 160-167. [CrossRef]

6. Hospital, X.F.; Hierro, E.; Fernández, M. Effect of reducing nitrate and nitrite added to dry fermented sausages on the survival of Salmonella Typhimurium. Food Res. Int. 2014, 62, 410-415. [CrossRef]

7. Reig, M.; Toldrá, F. Residues of harmful chemicals and their detection techniques. In Meat Quality Analysis Advanced Evaluation Methods, Techniques, and Technologies, 1st ed.; Biswas, A.K., Mandal, P., Eds.; Academic Press (Elsevier): London, UK, 2020; pp. 173-183. [CrossRef]

8. Alirezalu, K.; Hesari, J.; Nemati, Z.; Munekata, P.E.S.; Barba, F.J.; Lorenzo, J.M. Combined effect of natural antioxidants and antimicrobial compounds during refrigerated storage of nitrite-free frankfurter-type sausage. Food Res. Int. 2019, 120, 839-850. [CrossRef]

9. EC 1129/2011 European Commission regulation (EU) n ${ }^{\circ} 1129 / 2011$ of 11 November 2011 amending Annex II to Regulation (EC) $\mathrm{n}^{\circ} 1333 / 2008$ of the European Parliament and of the Council by establishing a Union list of food additives. Off. J. Eur. Union 2011, $295,1-177$.

10. EC 780/2006 European Commission regulation (EU) n ${ }^{\circ} 780 / 2006$ amending Annex VI to Council Regulation (EEC) No 2092/91 on organic production of agricultural products and indications referring thereto on agricultural products and foodstuffs. Off. $J$. Eur. Union 2006, 137, 9-14.

11. Sebranek, J.G.; Jackson-Davis, A.L.; Myers, K.L.; Lavieri, N.A. Beyond celery and starter culture: Advances in natural/organic curing processes in the United States. Meat Sci. 2012, 92, 267-273. [CrossRef] [PubMed]

12. Augusto, P.E.D.; Soares, B.M.C.; Castanha, N. Conventional Technologies of Food Preservation; Elsevier Inc.: Amsterdam, The Netherlands, 2018; ISBN 9780128110324.

13. Leistner, L. Basic aspects of food preservation by hurdle technology. Int. J. Food Microbiol. 2000, 55, 181-186. [CrossRef]

14. Italian Ministry of Health, Determinazione di L. monocytogenes e Salmonella spp. nei Prodotti a Base di Carne Suina Destinati All'export negli USA-Criteri e Modalità di Gestione Dell'autocontrollo Aziendale e Modalità di Verifica Dell'autorità Competente. 2015. Available online: https://www.aslmn.net/docs_file_vet/Circ_MdS_16_09_2015_Listeria_Salmonella_suino_export_USA. pdf (accessed on 30 August 2021).

15. Bajovic, B.; Bolumar, T.; Heinz, V. Quality considerations with high pressure processing of fresh and value added meat products. Meat Sci. 2012, 92, 280-289. [CrossRef] [PubMed]

16. Garriga, M.; Marcos, B.; Martín, B.; Veciana-Nogués, M.T.; Bover-Cid, S.; Hugas, M.; Aymerich, T. Starter cultures and highpressure processing to improve the hygiene and safety of slightly fermented sausages. J. Food Prot. 2005, 68, 2341-2348. [CrossRef]

17. De Oliveira, T.L.C.; Ramos, A.L.S.; Ramos, E.M.; Piccoli, R.H.; Cristianini, M. Natural antimicrobials as additional hurdles to preservation of foods by high pressure processing. Trends Food Sci. Technol. 2015, 45, 60-85. [CrossRef]

18. Huang, H.W.; Hsu, C.P.; Wang, C.Y. Healthy expectations of high hydrostatic pressure treatment in food processing industry. J. Food Drug Anal. 2020, 28, 1-13. [CrossRef] [PubMed]

19. Barba, F.J.; Koubaa, M.; do Prado-Silva, L.; Orlien, V.; de Souza Sant'Ana, A. Mild processing applied to the inactivation of the main foodborne bacterial pathogens: A review. Trends Food Sci. Technol. 2017, 66, 20-35. [CrossRef]

20. Meloni, D. High-Hydrostatic-Pressure (HHP) Processing Technology as a Novel Control Method for Listeria monocytogenes Occurrence in Mediterranean-Style Dry-Fermented Sausages. Foods 2019, 8, 672. [CrossRef]

21. Roohinejad, S.; Koubaa, M.; Sant'Ana, A.S.; Greiner, R. Mechanisms of Microbial Inactivation by Emerging Technologies; Elsevier Inc.: Amsterdam, The Netherlands, 2018; ISBN 9780128110324.

22. Marcos, B.; Aymerich, T.; Dolors Guardia, M.; Garriga, M. Assessment of high hydrostatic pressure and starter culture on the quality properties of low-acid fermented sausages. Meat Sci. 2007, 76, 46-53. [CrossRef]

23. Rubio, B.; Possas, A.; Rincón, F.; García-Gímeno, R.M.; Martínez, B. Model for Listeria monocytogenes inactivation by high hydrostatic pressure processing in Spanish chorizo sausage. Food Microbiol. 2018, 69, 18-24. [CrossRef]

24. Bonilauri, P.; Grisenti, M.S.; Daminelli, P.; Merialdi, G.; Ramini, M.; Bardasi, L.; Taddei, R.; Cosciani-Cunico, E.; Dalzini, E.; Frustoli, M.A.; et al. Reduction of Salmonella spp. populations in Italian salami during production process and high pressure processing treatment: Validation of processes to export to the U.S. Meat Sci. 2019, 157, 107869. [CrossRef] 
25. Bonilauri, P.; Merialdi, G.; Ramini, M.; Bardasi, L.; Taddei, R.; Silvia, M.; Daminelli, P.; Cosciani-cunico, E.; Dalzini, E.; Angela, M.; et al. Modeling the behavior of Listeria innocua in Italian salami during the production and high-pressure validation of processes for exportation to the. Meat Sci. 2021, 172, 108315. [CrossRef] [PubMed]

26. Marcos, B.; Aymerich, T.; Garriga, M.; Arnau, J. Active packaging containing nisin and high pressure processing as post-processing listericidal treatments for convenience fermented sausages. Food Control 2013, 30, 325-330. [CrossRef]

27. Muñoz-Cuevas, M.; Guevara, L.; Aznar, A.; Martínez, A.; Periago, P.M.; Fernández, P.S. Characterisation of the resistance and the growth variability of Listeria monocytogenes after high hydrostatic pressure treatments. Food Control 2013, 29, 409-415. [CrossRef]

28. Balamurugan, S.; Gemmell, C.; Lau, A.T.Y.; Arvaj, L.; Strange, P.; Gao, A.; Barbut, S. High pressure processing during drying of fermented sausages can enhance safety and reduce time required to produce a dry fermented product. Food Control 2020, 113, 107224. [CrossRef]

29. Liu, Y.; Betti, M.; Gänzle, M.G. High pressure inactivation of Escherichia coli, Campylobacter jejuni, and spoilage microbiota on poultry meat. J. Food Prot. 2012, 75, 497-503. [CrossRef]

30. Rocchetti, G.; Falasconi, I.; Dallolio, G.; Lucini, L.; Rebecchi, A. Impact of hurdle technologies and low temperatures during ripening on the production of nitrate-free pork salami: A microbiological and metabolomic comparison. LWT 2021, 141, 110939. [CrossRef]

31. Hospital, X.F.; Hierro, E.; Stringer, S.; Fernández, M. A study on the toxigenesis by Clostridium botulinum in nitrate and nitritereduced dry fermented sausages. Int. J. Food Microbiol. 2016, 218, 66-70. [CrossRef]

32. ISO21807:2004 Microbiology of Food and Animal Feeding Stuffs_Determination of Water Activity; ISO: Geneva, Switzerland, 2004.

33. ISO15213:2003 Microbilogy of Food and Feeding Stuffs-Horizontal Method for the Enumeration od Sulfite-Reducing Bacteria Growing under Anaerobic Conditions; ISO: Geneva, Switzerland, 2003.

34. ISO6888-1:1999 Microbiology of Food and Animal Feeding Stuffs-Horizontal Method for the Enumeration of Coagulase-Positive Staphylococci (Staphylococcus Aureus and other Species)_Part 1: Technique Using Baird-Parker Agar Medium; ISO: Geneva, Switzerland, 1999.

35. ISO7932:2004 Microbiology of Food and Feeding Stuffs-Horizontal Method for the Enumeration of Presumptive Bacillus Cereus-Colonycount Technique at 30 Degrees C; ISO: Geneva, Switzerland, 2004.

36. ISO11290-2:2017 Microbiology of the Food Chain-Horizontal Method for the Detection and Enumeration of Listeria Monocytogenes and of Listeria Spp.—Part 2: Enumeration Method; ISO: Geneva, Switzerland, 2017.

37. ISO11290-1:2017 Microbiology of the Food Chain-Horizontal Method for the Detection and Enumeration of Listeria Monocytogenes and of Listeria Spp.—Part 1: Detection Method. International; ISO: Geneva, Switzerland, 2017.

38. ISO6579-1:2017 Microbiology of the Food Chain-Horizontal Method for the Detection, Enumeration and Serotyping of Salmonella-Part 1: Detection of Salmonella Spp; ISO: Geneva, Switzerland, 2007.

39. ISO18787:2017 Foodstuffs- Determination of Water Activity; ISO: Geneva, Switzerland, 2017.

40. Cardinali, F.; Milanović, V.; Osimani, A.; Aquilanti, L.; Taccari, M.; Garofalo, C.; Polverigiani, S.; Clementi, F.; Franciosi, E.; Tuohy, K.; et al. Microbial dynamics of model Fabriano-like fermented sausages as affected by starter cultures, nitrates and nitrites. Int. J. Food Microbiol. 2018, 278, 61-72. [CrossRef]

41. Mataragas, M.; Bellio, A.; Rovetto, F.; Astegiano, S.; Greci, C.; Hertel, C.; Decastelli, L.; Cocolin, L. Quantification of persistence of the food-borne pathogens Listeria monocytogenes and Salmonella enterica during manufacture of Italian fermented sausages. Food Control 2015, 47, 552-559. [CrossRef]

42. Higuero, N.; Moreno, I.; Lavado, G.; Vidal-Aragón, M.C.; Cava, R. Reduction of nitrate and nitrite in Iberian dry cured loins and its effects during drying process. Meat Sci. 2020, 163, 108062. [CrossRef]

43. Pini, F.; Aquilani, C.; Giovannetti, L.; Viti, C.; Pugliese, C. Characterization of the microbial community composition in Italian Cinta Senese sausages dry-fermented with natural extracts as alternatives to sodium nitrite. Food Microbiol. 2020, $89,103417$. [CrossRef]

44. Eyiler, E.; Oztan, A. Production of frankfurters with tomato powder as a natural additive. LWT Food Sci. Technol. 2011, 44, 307-311. [CrossRef]

45. Hayes, J.E.; Canonico, I.; Allen, P. Effects of organic tomato pulp powder and nitrite level on the physicochemical, textural and sensory properties of pork luncheon roll. MESC 2013, 95, 755-762. [CrossRef]

46. Patarata, L.; Martins, S.; Silva, J.A.; Fraqueza, M.J. Red wine and garlic as a possible alternative to minimize the use of nitrite for controlling Clostridium sporogenes and Salmonella in a cured sausage: Safety and sensory implications. Foods 2020, 9, 206. [CrossRef]

47. Marcos, B.; Aymerich, T.; Garriga, M. Evaluation of High Pressure Processing as an Additional Hurdle to Control Listeria monocytogenes and Salmonella enterica in Low-Acid Fermented Sausages. Food Microbiol. Saf. 2005, 70, 339-344. [CrossRef]

48. Martin, I.; Rodriguez, A.; Sanchez-Montero, L.; Padilla, P.; Cordoba, J.J. Effect of the Dry-Cured Fermented Sausage "Salchichón " Processing with a selected Lactobacillus sakei in Listeria monocytogenes and Microbial Population. Foods 2021, 10, 856. [CrossRef]

49. EC 2073/2005 EC Commission Regulation No 2073/2005 of 15 November 2005 on microbiological criteria for foodstuffs. Off. J. Eur. Union 2005, 338, 1-26.

50. Hayman, M.M.; Baxter, I.; O'Riordan, P.J.; Stewart, C.M. Effects of high-pressure processing on the safety, quality, and shelf life of ready-to-eat meats. J. Food Prot. 2004, 67, 1709-1718. [CrossRef] [PubMed] 
51. Gonzalez-fandos, E.; De Castro, M.V.; Martinez-laorden, A.; Perez-arnedo, I. Behavior of Listeria monocytogenes and Other Microorganisms in Sliced Riojano Chorizo (Spanish Dry-Cured Sausage) during Storage under Modified Atmospheres. Microorganisms 2021, 9, 1384. [CrossRef]

52. Van Reckem, E.; Geeraerts, W.; Charmpi, C.; Van Der Veken, D. Exploring the Link Between the Geographical Origin of European Fermented Foods and the Diversity of Their Bacterial Communities: The Case of Fermented Meats. Front. Microbiol. 2019, 10, 1-11. [CrossRef]

53. Oliveira, M.; Ferreira, V.; Magalhães, R.; Teixeira, P. Biocontrol strategies for Mediterranean-style fermented sausages. Food Res. Int. 2018, 103, 438-449. [CrossRef]

54. Peña-Meléndez, M.; Perry, J.J.; Yousef, A. Changes in thermal resistance of three Salmonella serovars in response to osmotic shock and adaptation at water activities reduced by different humectants. J. Food Prot. 2014, 77, 914-918. [CrossRef] [PubMed]

55. Farakos, S.M.S.; Frank, J.F.; Schaffner, D.W. International Journal of Food Microbiology Modeling the influence of temperature, water activity and water mobility on the persistence of Salmonella in low-moisture foods. Int. J. Food Microbiol. 2013, 166, 280-293. [CrossRef] [PubMed]

56. Finn, S.; Condell, O.; Mcclure, P.; Amézquita, A.; Fanning, S. Mechanisms of survival, responses, and sources of Salmonella in low-moisture environments. Front. Microbiol. 2013, 4, 331. [CrossRef] [PubMed]

57. Balamurugan, S.; Ahmed, R.; Chibeu, A.; Gao, A.; Koutchma, T.; Strange, P. International Journal of Food Microbiology Effect of salt types and concentrations on the high-pressure inactivation of Listeria monocytogenes in ground chicken. Int. J. Food Microbiol. 2016, 218, 51-56. [CrossRef] [PubMed]

58. Bover-Cid, S.; Belletti, N.; Aymerich, T.; Garriga, M. Modelling the impact of water activity and fat content of dry-cured ham on the reduction of Salmonella enterica by high pressure processing. MESC 2017, 123, 120-125. [CrossRef]

59. Hayman, M.M.; Kouassi, G.K.; Anantheswaran, R.C.; Floros, J.D.; Knabel, S.J. Effect of water activity on inactivation of Listeria monocytogenes and lactate dehydrogenase during high pressure processing. Int. J. Food Microbiol. 2008, 124, 21-26. [CrossRef] [PubMed]

60. Koseki, S.; Yamamoto, K. Water activity of bacterial suspension media unable to account for the baroprotective effect of solute concentration on the inactivation of Listeria monocytogenes by high hydrostatic pressure. Int. J. Food Microbiol. 2007, 115, 43-47. [CrossRef] 